\title{
Chemical and Electron Microscope Studies on Fractions Prepared From Coats of Bacillus Spores
}

\author{
By M. KONDO* AND THE LATE J. W. FOSTER \\ Department of Microbiology, The University of Texas, \\ Austin, Texas 78712, U.S.A.
}

(Accepted for publication 21 December 1966)

\begin{abstract}
SUMMARY
'Coat fractions' were prepared from spores of six Bacillus species by mechanical disruption, centrifugation, and digestion with lysozyme. The coats were successively extracted with dilute $\mathrm{NaOH}$, treated sonically (mildly), and digested with the proteolytic enzyme preparation Pronase. Bacillus megaterium QM B 1551 was studied in detail. Electron microscopic studies were made at the various stages. Three fractions were obtained and partly characterized chemically. The alkali-soluble fraction consisted mainly of protein(s). The paracrystal fraction solubilized by sonic treatment consisted mainly of protein with a chemical composition and physical characteristics similar to those of keratins. The final resistant residue fraction of the coats after hydrolysis contained amino acids, phosphorus and muramic acid, and may be composed of a phosphomuramyl polymer to which a peptide and/or protein is linked. Electron microscopic observation suggested that the spore coat of B. megaterium QM B 1551 consisted of at least three components: a middle, paracrystal fraction is sandwiched between or 'cemented' with the alkali-soluble fraction on one side and the resistant residue layer on the other. Large differences were found in the composition of the coats and in the $\mathbf{P}$ contents of the resistant residue of the various organisms.
\end{abstract}

\section{INTRODUCTION}

The spore coat constitutes a major part of the bacterial spore, in terms of both anatomy and mass. The coat is an important structure which probably plays a role in the resistance of the bacterial spore; it is also the initial contact site for germinative substances. The knowledge of chemical and physical constitutions of this complicated architecture will facilitate the studies on resistance and germination mechanisms in bacterial spores. The bulk of this coat has an amino acid composition similar to proteins (Salton \& Marshall, 1959; Hunnel \& Ordal, 1961; Warth, Ohye \& Murrell, 1963; Snoke, 1964). It has been also reported that wide differences are found in the proportions of amino acids and in the phosphorus contents of coats from different species (Fitz-James, 1955 a, $b$; Strange \& Dark, 1956; Salton, 1964). Spore coats consist of at least two distinct layers (Robinow, 1960; Ohye \& Murrell, 1962; Warth et al. 1963) but only the overall composition has been reported, inasmuch as no one has yet succeeded in stripping the individual layers; furthermore, the criteria of 'pure' coats are arbitrary. The present report describes the isolation of individual layers from the spore coat and their chemical and physical characteristics.

* Present address: Faculty of Pharmaceutical Sciences, Osaka University, Toyonaka, Japan, 


\section{METHODS}

Bacteriological. Most of the work was done with Bacillus megaterium QM B 1551 (Levinson \& Sevag, 1953). Other strains used were: B. megaterium ATCC 19213 (formerly known as 'Texas strain'); B. megaterium ATCC13368; B. polymyxa ATCC 842; B. subtilis ATCC6633; B. licheniformis ATCC9259. Bacilli from an overnight nutrient agar slope suspended in sterile de-ionized water were spread on the surface of agar of the following composition. Solution A: glucose, $1.0 \mathrm{~g}$; Basamine (AnheuserBusch, Inc., St Louis), $0.5 \mathrm{~g}$.; $\mathrm{MgSO}_{4} .7 \mathrm{H}_{2} \mathrm{O}, 0.2 \mathrm{~g}$; $\mathrm{NaCl}, 0.1 \mathrm{~g}$; L-glutamic acid, 1.0 g.; $\mathrm{CaCl}_{2} .2 \mathrm{H}_{2} \mathrm{O}, 6.6 \mathrm{mg}$.; $\mathrm{MnSO}_{4} .5 \mathrm{H}_{2} \mathrm{O}, 7 \cdot 8 \mathrm{mg}$; $\mathrm{ZnSO}_{4} .7 \mathrm{H}_{2} \mathrm{O}, 17 \cdot 8 \mathrm{mg}$; $\mathrm{FeSO}_{4} \cdot 7 \mathrm{H}_{2} \mathrm{O}, 18 \cdot 3 \mathrm{mg}$.; agar (Difco), $25 \mathrm{~g}$.; de-ionized water, $800 \mathrm{ml}$.; adjusted to pH 6.9. Solution $\mathrm{B}:\left(\mathrm{NH}_{4}\right)_{2} \mathrm{HPO}_{4}, 1.0 \mathrm{~g}$.; $\mathrm{KH}_{2} \mathrm{PO}_{4}, 5.0 \mathrm{~g}$.; de-ionized water, $200 \mathrm{ml}$.; adjusted to $\mathrm{pH} 6.9$. Four hundred ml. of solution $\mathrm{A}$ were mixed with $100 \mathrm{ml}$. of solution $B$ after autoclaving each, and the resulting medium poured to a depth of about $0.5 \mathrm{~cm}$. into aluminum-foil-covered sterile aluminum dishes $(17 \times 25 \mathrm{~cm}$.). After 4 days of incubation at $37^{\circ}$, the surface growth was rinsed off with a small volume of cold sterile de-ionized water and the small proportion of vegetative organisms was removed by biphasic washing (Sacks \& Alderton, 1961). The spores were washed further by eight changes in cold sterile water, lyophilized, and stored in vacuum.

Spore coats were prepared by mechanical rupture of spores in a Nossal disintegrator (Nossal, 1953). The glass tube in the metal cylinder was charged with $4 \mathrm{~g}$. of Ballotini beads (size 12) and $7 \mathrm{ml}$. of water containing $200 \mathrm{mg}$. lyophilized spores. The cylinder was chilled in ice water after each 10 sec. This treatment was repeated until no intact spores were visible microscopically, usually a total of 6-10 min. The beads were removed by low-speed centrifugation and the coat particles were recovered and washed by centrifugation at $10,000 \mathrm{~g}$ in cold de-ionized water. Microscopic examination revealed no unbroken spores. Although consisting predominantly of pieces of integument, the 'coat fraction' probably also contained remnants of spore membranes (Fitz-James, 1960; Ohye et al. 1962; Sacks \& Thomas, 1965). Before use, the stock coat fractions were dialysed against de-ionized water overnight in a cold room.

Chemical. Organic and inorganic phosphorus (P) were determined by the FiskeSubbaRow method (Fiske \& SubbaRow, 1925). Hexosamine, including muramic acid (Strange, 1960) was analysed by the Rondle-Morgan method (Rondle \& Morgan, 1955) in samples hydrolysed with $6 \mathrm{~N}-\mathrm{HCl}$ in a sealed tube for $8 \mathrm{hr}$ at $105^{\circ}$. The $\mathrm{HCl}$ was removed in vacuum before analysis. Muramic acid was detected (Barker \& Summerson, 1941) on samples eluted from thin-layer chromatograms. Amino acids were determined by the ninhydrin procedure (Moore \& Stein, 1948), with L-alanine as a standard, after hydrolysis with $6 \mathrm{~N}-\mathrm{HCl}$ in a sealed tube for $25 \mathrm{hr}$ at $105^{\circ}$ and vacuum removal of the HCl. Cystine was determined according to Kassel \& Brand (1938). The molar ratios of amino acids were obtained by means of a Beckman model 120-G amino acid analyser.

Chromatography. Most of the chemical components of the spore-coat fractions were identified by thin-layer chromatography on silica gel $G$ (Warner-Chilcott Laboratories, Richmond, California, U.S.A.). Solvents used were as follows: for 2dimensional separation of amino acids, $n$-butanol + acetic acid + water $(4+1+1$, by vol.) followed by phenol + water $(4+1$, by vol.); for water-soluble dinitrophenylamino acids (DNP-amino acids), $n$-butanol + acetic acid + water $(4+1+1$, by vol.); for 
ether-soluble DNP-amino acids, chloroform + methanol + acetic acid $(95+5+1$, by vol.); for polyols, $n$-propanol + ammonium hydroxide (sp.gr. $0 \cdot 88)+$ water $(6+3+1$, by vol.).

Presumptive identification of lysine was made with two-dimensional chromatography on Whatman no. 1 paper, with the solvents: $n$-propanol $+24 \%$ ammonium hydroxide (sp.gr. 0.88$)(2+1$, by vol.) followed by methanol + water $+10 \mathrm{~N}-\mathrm{HCl}+$ pyridine $(80+17 \cdot 5+2 \cdot 5+10$, by vol.). Amino sugars were chromatographed on Whatman no. 3 paper, with $n$-butanol + pyridine $+0.4 \%(\mathrm{w} / \mathrm{v})$ glacial acetic acid in water $(60+35+25$, by vol.) followed by phenol + water $(4+1$, by vol.). On occasion, both hexosamine and amino acids were detected on 2-dimensional thin-layer chromatograms developed with $n$-butanol + glacial acetic acid + water $(4+1+1$, by vol.) and phenol + water $(4+1$, by vol.).

Other determinations. $N$-Terminal amino acids were identified by Sanger's fluorodinitrophenylation method (Sanger, 1945, 1949), substituting $\mathrm{NaHCO}_{3}+\mathrm{KOH}$ for trimethylamine; the bacterial DNP-derivatives were compared with authentic DNPamino acids. Partial hydrolysis of the resistant residue was done in $2 \mathrm{~N}-\mathrm{HCl}$ for $3 \mathrm{hr}$ at $100^{\circ}$.

For the X-ray diffraction of paracrystal fraction, a model ADP-101 B Toshiba X-ray diffraction apparatus was employed. The sample powder filled into capillary tubing was placed in the apparatus at the distance of $3 \mathrm{~cm}$. from the camera. The time of exposure was $10 \mathrm{hr}(30 \mathrm{kV}, 15 \mathrm{~mA})$.

Electron microscopy. A model EMU 3-G RCA electron microscope was employed. Specimens were freeze-dried on freshly cleaned mica, shadowed with platinum palladium $(80+20, w / w)$ and coated with carbon. The carbon-coated preparation was floated with distilled water from the mica onto a 200 -mesh wire grid.

\section{RESULTS}

\section{Fractionation of spore coats}

Figure 1 depicts the sequence of steps for separating individual components from spore coats. The fractionation was done on approximately $1 \mathrm{~g}$. samples of coats.

Lysozyme digestion. This treatment eliminates mucopeptide regarded as cortical in origin and not an integral part of the spore coat (see Warth et al. 1963; Warth, 1965). Nearly one-third of the weight of the coat fraction was removed in this step.

$\mathrm{NaOH}$ extraction. Lysozyme-digested coats were suspended in de-ionized water to an extinction of 0.8 and brought to $50^{\circ}$. Upon adding $\mathrm{NaOH}$ the extinction rapidly decreased by about $50 \%$ (Fig. 2). The alkaline extract was neutralized with $\mathrm{HCl}$ and concentrated in vacuum to a small volume in a rotary evaporator; a considerable amount of a white amorphous material precipitated. This water-insoluble material was dialysed against de-ionized water for 2 days in a cold room; it is designated as the 'alkali-soluble fraction'.

Sonic treatment. When the sediment undissolved by the $\mathrm{NaOH}$ was agitated with glass rod to make a homogeneous suspension, the sediment had a strong tendency to form aggregates difficult to disperse. A homogeneous suspension was obtained by mild sonic treatment. $\mathrm{NaOH}$-extracted coats $(150 \mathrm{mg}$.) were suspended in $15 \mathrm{ml}$. de-ionized water in a $20 \mathrm{ml}$. beaker (diam. $3.5 \mathrm{~cm}$., height $4.5 \mathrm{~cm}$.). Sonic treatment was done in the cold with a Branson Sonifier (Branson Instruments, Inc., Danbury, 
Conn., U.S.A.) at power setting 3 for $5 \mathrm{~min}$. The supernatant liquid obtained by centrifugation of the sonically treated suspension at $10,000 \mathrm{~g}$ for $20 \mathrm{~min}$. was faintly opalescent. Upon concentration in vacuum, a considerable quantity of crystalloid

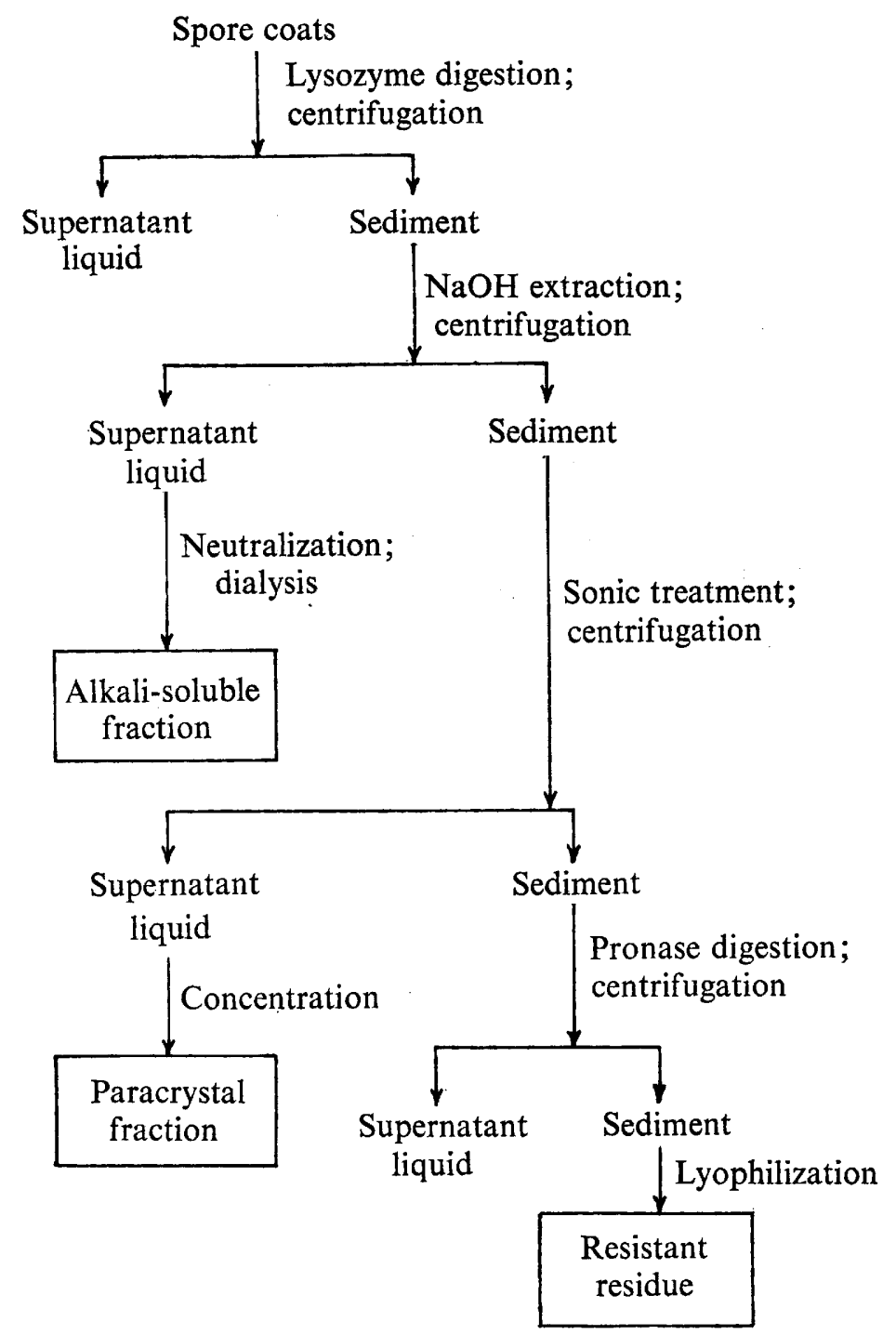

Fig. 1. Scheme for fractionation of spore coats into three products (denoted by boxes).

Details of each step are given in the text. Centrifugation was at $10,000 \mathrm{~g}$ for $20 \mathrm{~min}$.

organic material precipitated (P1. 1, figs. 1-4) along with some amorphous matter and was recovered on a sintered-glass filter. The content of this fraction in the lysozymetreated spore coat of Bacillus megaterium QM B 1551 was $30 \%$. The fraction was designated as the 'paracrystal fraction'.

The coat residues not solubilized by mild sonic treatment represented, in different strains, from one-half to four-fifths of the original coat weight (Table 1). They were 
digested with the proteolytic enzyme preparation Pronase (California Biochemical Corp., Los Angeles, Calif., U.S.A.); the Pronase-insoluble residues, amounting to about one-quarter to one-half of the weights of the original lysozyme-digested coats (Table 1), were washed thoroughly by centrifugation in water at $10,000 \mathrm{~g}$ for $20 \mathrm{~min}$., dialysed against distilled water overnight in the cold room, and designated as 'resistant residue'.

Thus, the spore coats were resolved into three fractions: (1) alkali-soluble fraction, (2) paracrystal fraction, (3) resistant residue.

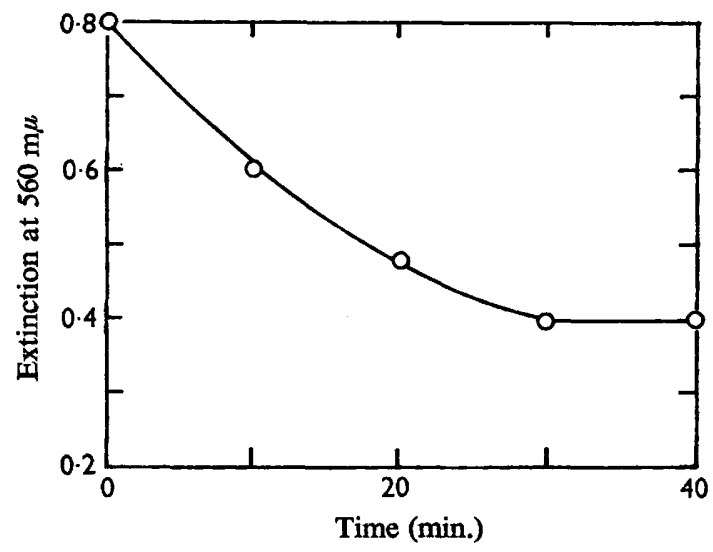

Fig. 2. Change in extinction (at $560 \mathrm{~m} \mu$ ) of lysozyme-treated spore coats of Bacillus megaterium QM B1551 during extraction with $0.06 \mathrm{~N}-\mathrm{NaOH}$ at $50^{\circ}$.

\section{Phosphorus contents of spore coat fractions}

The $\mathbf{P}$ content of the coat fractions differed widely in the various strains, from a low of 0.23 to $3.2 \%$ (see Fitz-James, 1955a, $b$; Fitz-James \& Young, 1959b; Warth et al. 1963; Levinson \& Hyatt, 1964). Coats with the higher P contents evidently contained most of their $\mathbf{P}$ in the resistant residue in which it became concentrated through the successive digestions. However, the other three strains showed no such $\mathrm{P}$ enrichment. From these and the findings of others (Fitz-James, 1955a, b; Warth et al. 1963), it is obvious that high coat-P is not an essential attribute of the spore. The final resistant residue from Bacillus megaterium QM B 1551 containing the surprisingly high content of coat-P has been correlated with the presence of a dense outer coat (Fitz-James \& Young, 1959a, b; Warth et al. 1963).

\section{Electron microscopy of spore coats}

Coats of Bacillus megaterium QM B 1551 (P1. 2) were not strikingly altered in appearance by lysozyme digestion (P1. 3, figs. 6 and 7). Indications of heterogeneity in the construction of the coats are seen in P1. 3, especially fig. 7. Two layers can be seen: one appears to be composed of more or less uniform spherical particles (Pl. 3, fig. 7), and the other smooth and relatively featureless, although this also may be layered (P1. 3, fig. 6). The smooth layer disappeared after alkali-digestion and aggregated material can be seen on or around the treated coats (P1. 4, fig. 8). An interpretation possible from the photographs is that one of the coat layers is composed of 


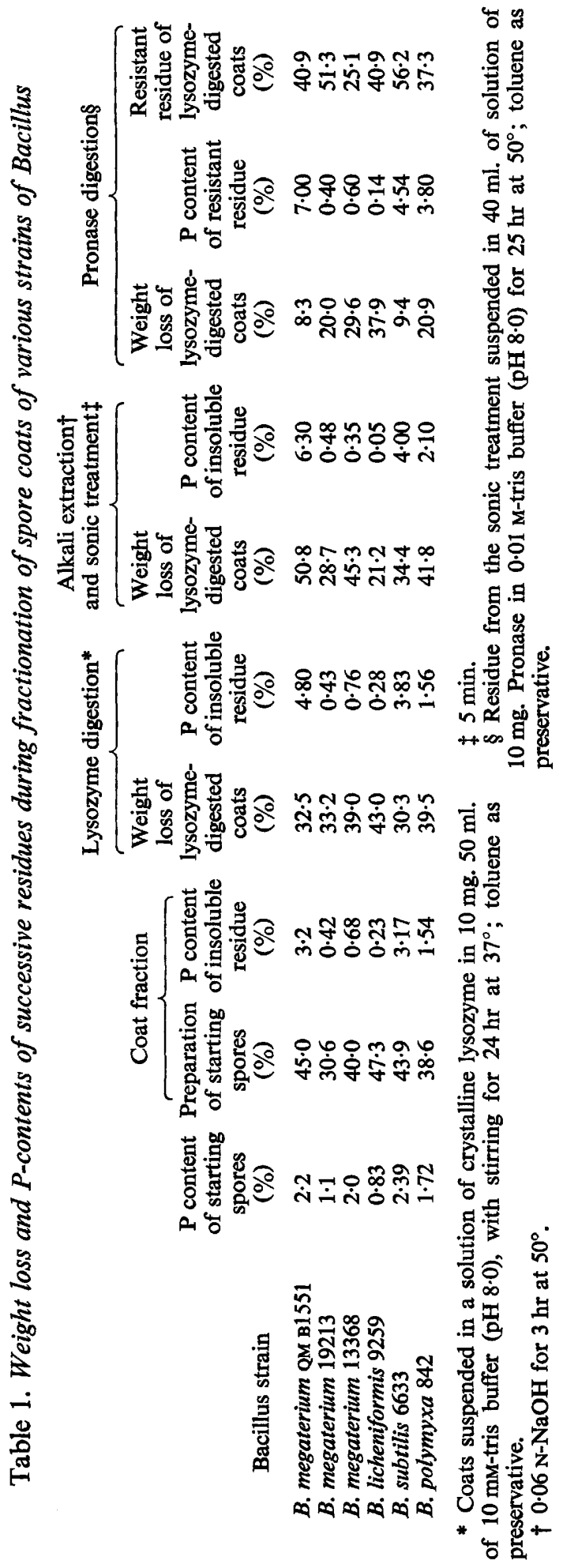


discrete particles which can be dissociated in conjugated form from their normal array by alkali treatment. The particle layer is probably overlayered with the alkalisoluble material; removal of the latter permits the release of the particles and this is expedited by mild sonic treatment. The particles are believed to constitute the bulk of the paracrystal fraction and were obtained readily by sonic treatment only after extraction with alkali. The resistant residue of the coats after sonic treatment and sedimentation in the centrifugation had a distinct ultramicroscopic structure (Pl. 4, fig. 9) and was almost devoid of the larger particles described above. These particles probably represent the major portion of the paracrystal fraction which, as already seen, spontaneously associate into regular macrostructures.

From the results of the electron microscopy, one can imagine, as a working hypothesis, that the spore coat of Bacillus megaterium QM B 1551 consists of at least three components: a middle, particulate layer (the paracrystal fraction) is sandwiched between or 'cemented' with the alkali-soluble layer on one side and the resistantresidue layer on the other.

Table 2. Amino acid composition* of fractions from spore coats of Bacillus megaterium $\mathrm{QM}$ B1551

\begin{tabular}{lccc} 
& \multicolumn{3}{c}{ Residues per 100 total residues } \\
\cline { 2 - 4 } Amino acid & $\begin{array}{c}\text { Alkali-soluble } \\
\text { fraction }\end{array}$ & $\begin{array}{c}\text { Paracrystal } \\
\text { fraction }\end{array}$ & $\begin{array}{c}\text { Resistant } \\
\text { residue }\end{array}$ \\
Lysine & $7 \cdot 5$ & $2 \cdot 5$ & $18 \cdot 4$ \\
Histidine & $4 \cdot 8$ & $2 \cdot 4$ & $3 \cdot 1$ \\
Arginine & $6 \cdot 2$ & $5 \cdot 6$ & $4 \cdot 5$ \\
Aspartic acid & $9 \cdot 8$ & $15 \cdot 0$ & $11 \cdot 0$ \\
Threonine & $4 \cdot 0$ & $2 \cdot 9$ & $5 \cdot 1$ \\
Serine & $5 \cdot 1$ & $6 \cdot 6$ & $6 \cdot 1$ \\
Glutamic acid & $7 \cdot 5$ & $8 \cdot 3$ & $10 \cdot 0$ \\
Proline & $6 \cdot 5$ & $1 \cdot 2$ & $4 \cdot 8$ \\
Glycine & $12 \cdot 1$ & $16 \cdot 0$ & $6 \cdot 2$ \\
Alanine & $5 \cdot 6$ & $4 \cdot 7$ & $4 \cdot 7$ \\
Cystine (half) & $1 \cdot 3$ & $8 \cdot 2 \dagger$ & 1.9 \\
Valine & $4 \cdot 0$ & $2 \cdot 3$ & $3 \cdot 8$ \\
Methionine & $1 \cdot 1$ & $1 \cdot 0$ & $3 \cdot 5$ \\
Isoleucine & $3 \cdot 2$ & $2 \cdot 0$ & $5 \cdot 8$ \\
Leucine & $5 \cdot 1$ & $\cdot 27$ & Trace \\
Tyrosine & $11 \cdot 6$ & $2 \cdot 1$ & $4 \cdot 9$ \\
Phenylalanine & $4 \cdot 7$ & $6 \cdot 7$ & $5 \cdot 4$
\end{tabular}

* Determined with a Beckman model $120 \mathrm{~B}$ amino acid analyser.

$\uparrow$ Determined as cysteic acid on a separate sample of protein oxidized with performic acid (Moore, 1963).

\section{The alkali-soluble fraction of Bacillus megaterium $Q M B 1551$}

This material was insoluble in water at $\mathrm{pH} 7$ but was soluble at pH 9.5. It did not move from the origin in thin-layer chromatography with $n$-butanol + acetic acid + water as solvent and it gave a strong reaction with ninhydrin. The material was treated again with lysozyme to eliminate contamination with mucopeptide. After acid hydrolysis, numerous amino acids were identified, by combinations of one- and two-dimensional thin-layer chromatograms, suggestive of protein. The $\mathbf{P}$ content was relatively low $(0.9 \%)$. The amino acid analysis showed all of the usual amino acids (Table 2) of proteins. Thus, the alkali-soluble fraction appeared to consist predominantly of one 
or more protein(s) distinct in amino acid composition (Table 2) from that in the other fractions described below.

The alkali-soluble protein had more glycine than most proteins, with the notable exception of the collagens, which are extremely rich in this amino acid. Collagens also lack cystine; there was a very low cystine content in the bacterial alkali-soluble product. Perhaps the most outstanding finding was the very high content $(12.0 \%)$ of tyrosine. In distinction from the collagens where this tyrosine occurs in very low concentrations, the tyrosine content of the alkali-soluble proteins from the spore coats was higher than that of any of the 253 proteins whose analyses were compiled by Tristam \& Smith (1963). Only papain has a tyrosine content approaching that of the protein from these spore coats.

Other major differences between the three spore-coat protein fractions (Table 2) are in the amounts of aspartic acid, lysine, and proline.

During the alkali extraction, the spore coats agglutinated strongly. This suggested that surface charges, either absent or masked by the alkali-soluble protein before its extraction, were generated by disruption of the normal combination (possibly a weak ester linkage involving e.g. the tyrosyl hydroxyls) between the protein and the rest of the spore coat.

Table 3. Effect of various agents on the solubility of the paracrystal fraction from spore coats of Bacillus megaterium $Q M B 1551$

\begin{tabular}{|c|c|}
\hline Agent and final concentration & $\begin{array}{l}\text { Effect on colloidal suspension } \\
\text { of paracrystal fraction } \\
(5 \mathrm{mg} . / \mathrm{ml} \text {.) in water }\end{array}$ \\
\hline $\begin{array}{l}\mathrm{Na} \text { laurylsulphate, } 0.1 \% \\
\text { Polyethylene lauryl alcohol, } 0.1 \% \\
\mathrm{Na} \text { ethylenediamine tetracetate, } 0.1 \% \\
\mathrm{Na} \text { bisulphite, } 0.1 \% \\
\mathrm{Na} \text { hydrosulphate, } 0.1 \% \\
\beta \text {-Mercaptoethanol, } 0.1 \% \\
\text { Ascorbic acid, } 0.1 \% \\
\mathrm{Cysteine,} 0.1 \text { and } 1.0 \% \\
\mathrm{KCl}, 0.5 \text { and } 1.0 \mathrm{M} \\
\mathrm{NaOH}, 0.1,0.5 \text { and } 1.0 \mathrm{~N} \\
\mathrm{HCl}, 0.1,0.5 \text { and } 1.0 \mathrm{~N} \\
\mathrm{H}_{2} \mathrm{O}_{2}, 0.1 \% \text { (w/v) } \\
\mathrm{Na} \text { iodacetate, } 0.01 \text { and } 0.1 \mathrm{M} \\
\mathrm{Cetyl} \text { trimethylammonium bromide, } 0.1 \text { and } 0.5 \%\end{array}$ & $\begin{array}{l}\text { Clearing } \\
\text { Partial clearing } \\
\text { Partial clearing } \\
\text { White precipitate } \\
\text { White precipitate } \\
\text { White precipitate } \\
\text { White precipitate } \\
\text { Tan precipitate } \\
\text { Tan precipitate } \\
\text { Tan precipitate } \\
\text { Tan precipitate } \\
\text { None } \\
\text { None } \\
\text { None }\end{array}$ \\
\hline
\end{tabular}

The paracrystal fraction of Bacillus megaterium $Q M B 1551$

The lyophilized material was a slightly tan-coloured fluffy product; in water it formed a light amber opalescent solution. The colloidal solution was reactive with several reagents (Table 3 ). Sodium lauryl sulphate (SLS) strikingly enhanced the solubility of the paracrystal fraction. Sonic treatment of the $\mathrm{NaOH}$-extracted coats in $0.1(\mathrm{w} / \mathrm{v})$ SLS was a much more efficient means of obtaining this fraction than treatment in water alone. A cationic surface-active agent, cetyl trimethylammonium bromide, did not have this effect.

Several compounds, notably some reducing agents, elicited the opposite reaction, namely, a precipitation of the paracrystal fraction. The solution turned colourless and yielded a copious white amorphous precipitate (Table 3). Other reagents, including 
cysteine, also induced precipitation although less effectively and the products were tan-coloured. These observations suggest that the paracrystal fraction had easily reducible groups and that, while reduced, these reacted inter- and possibly intramolecularly to form an insoluble polymer.

The behaviour in SLS also suggested that the paracrystal fraction broke into smaller components, resulting in increased solubility. The principal effect of the reducing agents also appeared to be one of solubilization, as suggested by the clearing of a colloidal suspension. The precipitation developed secondarily, presumably from

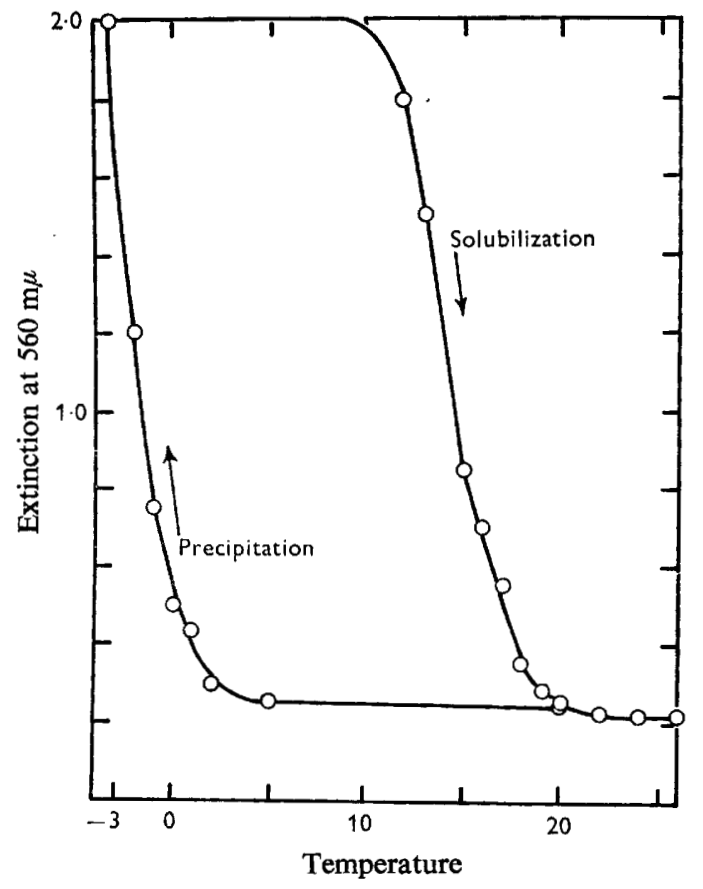

Fig. 3. Temperature-dependent, reversible 'precipitation solubilization' of paracrystal fraction, $5 \mathrm{mg}$. $/ \mathrm{ml}$. distilled water.

a random interaction of the reduced fragments or subunits. This precipitation of the reduced units was markedly hindered by SLS. Consequently, conducting the reduction in the presence of SLS led to the formation of stable solutions of much higher concentrations than were otherwise obtainable. Comparable effects of reducing compounds and detergents on proteins dissociable into subunits is well known (Putnam, 1953; Reithal, 1963). The precipitation and solubilization were reversible and temperaturedependent, with curves exhibiting a hysteresis (Fig. 3 ). There was a $12^{\circ}$ differential in the temperatures which initiated precipitation and solubilization in this experiment. The phenomenon was seen in SLS solution as intensely as in water.

Ultracentrifugation in a Spinco Model E instrument of a solution of paracrystal material in $0.1 \%(\mathrm{w} / \mathrm{v})$ SLS showed the material to be markedly heterogeneous in respect to macromolecular components. In a comparable SLS solution to which $0.1 \%(\mathrm{w} / \mathrm{v})$ mercaptoethanol was added, the several fast-moving peaks disappeared; there appeared instead a single rather broad peak that moved very slowly. The 
heterogenous heavier macromolecular components were dissociated into smaller components by the mercaptoethanol. These ultracentrifugation experiments were only preliminary ones, and it is not yet possible to decide whether the smaller particles are a homogeneous single component. The major slow-moving band was indicative of very small particles of macromolecules, estimated to be in the range of 4 Svedberg units. Mercaptoethanol and sodium lauryl sulphate had a decided effect on 'dissociation' of the paracrystal material, on elimination of much of the macromolecular heterogeneity, and on stabilization of dissociated solutions.

An acid hydrolysate $\left(6 \mathrm{~N}-\mathrm{HCl}\right.$ for $8 \mathrm{hr}$ at $\left.105^{\circ}\right)$ of the paracrystal fraction contained a variety of amino acids, muramic acid, and $P$ in the ratio of 40 (L-alanine equivalents):6:1. The hexosamine content was $0.8 \%$ but the reacting compound could not be identified as acetylglucosamine, glucosamine or galactosamine by using authentic reference samples. The muramic acid and $P$ values may indicate contamination of the main protein component with a small amount of the resistant residue rich in phosphomuramic acid described below. The paracrystal material proved to have an unusual

Table 4. Cysteine content of representative fractions derived from spore coats of Bacillus megaterium QM $B 1551$

\begin{tabular}{lc}
$\quad$ Fraction & Weight \\
Whole coats & $(\%)$ \\
Alkali-soluble & 1.7 \\
Paracrystal material & nil \\
Resistant residue & 6.6 \\
\hline
\end{tabular}

amino acid composition (Table 2) more than half of the amino acids present were glycine, aspartic acid, glutamic acid and cysteine. More than four-fifths of the residues were accounted for by eight amino acids; more than one of every four residues was glycine. There was a high proportion of cysteine (half)-one of every 12 amino acid residues. Also noteworthy is the high proportion of the dicarboxylic acids: nearly one of every four amino acids residues was an aspartic acid or glutamic acid.

The paracrystal fraction was the only fraction rich in cysteine (Table 4) and it accounted for the bulk of the cysteine in the whole coats.

The X-ray diffraction photograph for the paracrystal fraction showed the following major rings : $10 \cdot 1,4 \cdot 8,3 \cdot 0,2 \cdot 6,2 \cdot 3,2 \cdot 1,1 \cdot 9$ and $1 \cdot 7 \AA$. The inner rings corresponding to $10 \cdot 1$ and $4.8 \AA$ were not so sharp as the other six rings, which were very sharp. Thus, two kinds of rings appeared in the X-ray diffraction photographs. The two inner rings $(10 \cdot 1,4 \cdot 8 \AA)$ corresponded to those of $\alpha$-keratin. Only the two inner rings were obtained from the fraction of germinated spore coat.

The above results suggest that the paracrystal fraction consists of at least keratin-like substance as a basal structure.

\section{The resistant residue fraction of Bacillus megaterium $Q M B 1551$}

The various components in a $6 \mathrm{~N}-\mathrm{HCl}$ hydrolysate were identified with the aid of thin-layer chromatography and estimated with the amino acid analyser. The composition suggested that the resistant residue contained a phosphomuramyl polymer in combination with peptide and/or protein. However, about one-third of the weight of the resistant residue was unaccounted for. The presence of aspartic acid, glycine, 
and glutamic acid in substantial amounts might suggest major contamination with incompletely removed paracrystal fraction, but this was contradicted by the low content of cysteine.

The distinctiveness of the amino acid composition of the resistant residue was emphasized by the exceptionally high proportion of lysine; nearly one of every five of the identifiable amino acid residues was a lysine. The only protein reported to have a comparably high lysine content is cytochrome $C$ (Tristam \& Smith, 1963). If, alternatively, the high lysine is in the usual kind of side chain of polymucopeptide (Weidel \& Pelzer, 1965), correspondingly high proportions of alanine, aspartic acid, glutamic acid and perhaps glycine would be expected. (There was no indication of 2,6-diaminopimelic acid in the results furnished by the amino acid analyser.) Since the amounts of the latter amino acids did not suggest the usual type of mucopeptide, we concluded that the resistant residue contained either a protein or a peptide of composition distinguished by an abundance of lysine. In addition to the known amino acids, three other significant ninhydrin-positive peaks, estimated to comprise less than $15 \%$ of the total, were recorded by the amino acid analyser. One of these unidentified components eluted from the analyser column before lysine, where a hexosamine was to be expected. A second peak was located just after the position of cysteic acid and well before aspartic acid. The third component was detected as a relatively broad peak whose apex developed shortly after that of phenylalanine and overlapped it.

Of the organic compounds identified in the hydrolysate, muramic acid was by far the most abundant (Table 5). Contrary to the usual finding with cell walls of vegetative bacteria (Salton, 1964) and despite deliberate attempts to detect it, no significant amounts of hexosamine were found.

The usually high $P$ content was paralleled by the high total ash; more than one-quarter of the weight of the resistant residue was recovered as inorganic matter after ignition. The cations in this ash were not investigated but, since it contained $25 \% \mathrm{P}$, a reasonable inference is that the mineral matter was composed primarily of phosphate(s).

\section{Table 5. Some components of resistant residue fraction of spore coats} of Bacillus megaterium QM B1551

$\begin{array}{lc}\text { Component } & \begin{array}{c}\text { Amount in resistant } \\ \text { residue }(\%, \mathrm{w} / \mathrm{w})\end{array} \\ \text { Amino acids } & 27 \cdot 8^{*} \\ \text { Muramic acid } & 14 \cdot 5 \dagger \\ \text { Glucosamine } & \text { Trace } \\ \text { Total-N } & 5 \cdot 06 \\ \text { P } & 7.0 \\ \text { Ash } & 25.9\end{array}$

* L-Alanine equivalents (Moore, 1963) in acid-hydrolysed sample. † Glucosamine equivalents (Rondle \& Morgan, 1955) in acid-hydrolysed sample.

Partial hydrolysis of the resistant residue. Digestion with $2 \mathrm{~N}-\mathrm{HCl}$ at $100^{\circ}$ for $3 \mathrm{hr}$ dissolved most of the resistant residue. The soluble material was passed through a column of Dowex 50 ion exchange resin $\left(\mathrm{H}^{+}\right.$form); almost none of the $\mathrm{P}$ was adsorbed. The solution was then passed through a Dowex 1 (chloride form) column followed by $0 \cdot 1 \mathrm{M}-\mathrm{NaCl}$ as eluent. The several eluate fractions were analysed for 
orthophosphate and for organo-P. Three P-containing fractions were separated. The first fraction, containing $50 \%$ of the soluble $P$ (all organo-P), was not adsorbed by the Dowex 1 (more details of this fraction below). The second P-containing fraction was discharged in the first $100 \mathrm{ml}$. of eluent; it represented $38 \%$ of the soluble $\mathrm{P}$ and was identified as orthophosphorus. The third P-containing fraction contained $12 \%$ of the soluble $\mathbf{P}$ and was recovered in the second $100 \mathrm{ml}$. of eluent. No additional $\mathbf{P}$ was eluted in three further $100 \mathrm{ml}$. volumes of $\mathrm{NaCl}$ solution. On a thin-layer chromatogram the third fraction yielded a single P-containing spot. After hydrolysis in $6 \mathrm{~N}-\mathrm{HCl}$ for $8 \mathrm{hr}$ at $105^{\circ}$, the only products detectable were orthophosphorus and muramic acid. The P-containing compound in fraction 3 probably was, therefore, a phosphomuramic acid.

The organo-P in the first fraction showed only one $\mathbf{P}$ spot which did not move from the origin in thin-layer chromatograms. The spot reacted very quickly with reagents for amino acids (ninhydrin), for amino sugars (Elson-Morgan reagent) and for reducing sugars $\left(\mathrm{AgNO}_{3}\right)$. The P-containing material was eluted from a chromatogram, hydrolysed with $6 \mathrm{~N}-\mathrm{HCl}$ for $12 \mathrm{hr}$ at $100^{\circ}$, and the products subjected to 2-dimensional thin-layer chromatography. Only three components were detected; they were identified as muramic acid, lysine and ortho-P, in the molar ratio of $1: 1: 4 \cdot 8$. The unhydrolysed material did not react with fluorodinitrobenzene (FDNB), and DNP-lysine was not detected in the acid hydrolysate of an FDNB-treated specimen. The behaviour of the organo-P compound in fraction 1 , particularly its very low reactivity when unhydrolysed, suggests that it may be a polymer of phosphomuramic acid and lysine. In hydrolysates of the corresponding fraction obtained from resistant residues of the spore coats of Bacillus subtilis 6633 and B. polymyxa 842, lysine was not detected; only muramic acid and ortho-P were found and column fraction 1 from these two organisms is considered to be a phosphomuramic acid polymer.

\section{DISCUSSION}

This work indicates that the spore coats of some Bacillus species are chemically and anatomically heterogeneous. Further, in accord with results of other investigators, substantial differences exist in the proximate composition in different species, even between strains of one species. However, a semblance of the sameness along with diversity which characterizes the walls of vegetative bacterial cells (Salton, 1964; Weidel \& Pelzer, 1965) seems likely.

Judging from the exploratory analyses reported here, the coat chemistry suggests adaptation for a specialized function in the spore. Structural rigidity, physical toughness and metabolic inertness in biological systems are commonly provided by polysaccharides and protein. Identification of major components of the coats as a phosphomuramyl polymer [a 'murein' according to Weidel \& Pelzer (1965)], probably as a part of a phosphomucopeptide [a 'muropeptide' or a phosphomuroprotein (Weidel \& Pelzer, 1965)], and also a protein whose chemical and physical properties resemble those of keratins (Crewther, Fraser, Lennox \& Lindley, 1965), provides a rationale for coat structure and exoskeletal function. The high content of glycine, cystine and dicarboxylic acids found in the paracrystal fraction is characteristic of most keratins. It also seems likely that the high tyrosine content and perhaps the amounts of some of the other amino acids in the alkali-soluble protein, and also the high lysine content of the resistant residue, represent an adaptation for specialized function in the coat 
structure. The gross spore coats of Bacillus licheniformis contain tyrosine and glycine as major amino acids (Snoke, 1964). In all probability the cystine enrichment discovered by Vinter (1961) in bacterial spores and the keratin identified by X-ray crystallography in spore coats (Kadota, Iijima \& Uchida, 1965) correspond to the keratin-like protein isolated as our paracrystal fraction.

The electron micrographs and the physicochemical properties presented suggest that in Bacillus megaterium QM B 1551 at least one coat layer is composed of units more or less selectively dispersible by mild sonic treatment. Similar electron microscope evidence has been obtained with spore coats of Bacillus megaterium 988; these have yielded ultramicroscopic particles of various sizes and also discrete smaller units which appear to be uniform and primary (Williams, Holdom \& Foster, unpublished data). Recently, we have also succeeded in visualizing in situ in spore integuments regular arrays of uniform macromolecular particles in sheet-like layers (see Gerhardt \& Ribi, 1964, on ultrastructure in the exosporium of $B$. cereus spores). The layers of Bacillus megaterium 998 are composed of parallel chains of the particles (Suzuki, Williams \& Foster, unpublished data). Probably the tendency of solutions of the keratin fraction to associate spontaneously to form paracrystal structures (Pl. 1, figs. $1-4 ; \mathrm{Pl} .4$, fig. 8 ) is a reflexion of the presence of subunits which exhibit a polarity through an abundance of surface carboxyl and sulfhydryl groups (Table 2).

The exchangeable cations known to play significant roles in heat resistance (Alderton \& Snell, 1963) and in germination (Rode \& Foster, 1966a), and which are bound by isolated coat fractions (Foerster \& Foster, 1966), possibly interact with the dicarboxylic amino acids contained in abundance in the paracrystal fraction. Of course, interaction with coat muropeptides is also a possibility. Likewise, there is growing evidence of involvement of -SH groups, very likely those of the spore paracrystal keratin fraction, in radiation- and heat-resistance (Vinter, 1961) and in the dormancy-heat activation interplay (Gould \& Hitchins, 1963; Keynan, Evenchik, Halvorson \& Hastings, 1964; Keynan, Issahary-Brand \& Evenchik, 1965).

It may not be without significance that numerous substances, including hydrocarbons, long-chain alcohols, chelating agents, detergents, electrolytes and calcium ions, which have important effects on the germination of bacterial spores, also affect the association/dissociation equilibrium of proteins (Reithal, 1963) and may have implications for dormancy versus germination.

We are grateful to Mr M. G. Williams, Jun., The University of Texas Electron Microscope Laboratory, for the electron micrographs; Dr J. A. Smith, Clayton Foundation Biochemical Institute, and Mr M. Taylor and Dr R. L. Storck for assisttance with the ultracentrifugal analyses; Dr A. F. Riggs, Department of Zoology, and Mr J. E. Cunningham, Gene Control of Protein Structure and Function, for data obtained with the amino acid analyser; Dr K. Tomita, Faculty of Pharmaceutical Sciences, Osaka University, for X-ray diffraction analysis; Dr L. J. Rode for helpful discussions.

This work was supported in part by U.S. Public Health Service research grant AI-03564 from the National Institutes of Allergy and Infectious Diseases; the Office of Naval Research Contract No. 375-12; and the National Science Foundation research grant G-14568.

Dr J. W. Foster died on 9 April 1966. 


\section{REFERENCES}

Alderton, G. \& Snell, N. (1963). Base exchange and heat resistance in bacterial spores. Biochem. Biophys. Res. Comm. 10, 139.

BARKER, S. B. \& Summerson, W. H. (1941). The colorimetric determination of lactic acid in biological material. J. biol. Chem. 138, 535.

Crewther, W. G., Fraser, R. D. B., Lennox, F. G. \& Lindley, H. (1965). The chemistry of keratins. Adv. Protein Chem. 20, 191.

Fiske, C. H. \& SubBaRow, Y. (1925). The colorimetric determination of phosphorus. J. biol. Chem. 99, 375.

FITZ-JAMES, P. C. (1955a). The phosphorus fractions of Bacillus cereus and Bacillus megaterium. I. A comparison of spores and vegetative cells. Can. J. Microbiol. 1, 502.

FITZ-JAMES, P. C. (1955 b). The phosphorus fractions of Bacillus cereus and Bacillus megaterium. II. A correlation of the chemical with the cytological changes occurring during spore germination. Can. J. Microbiol. 1, 525.

Fitz-JAMES, P. C. (1960). Participation of the cytoplasmic membranes in the growth and spore formation of bacilli. J. biophys. biochem. Cytol. 8, 507.

Fitz-James, P. C. \& Young, I. E. (1959a). Comparison of species and varieties of the genus Bacillus. Structure and nucleic acid content of spores. J. Bact. 78, 743.

FITZ-JAMES, P. C. \& Young, I. E. (1959 b). Cytological comparison of spores of different strains of Bacillus megaterium. J. Bact. 78, 755.

Foerster, H. F. \& Foster, J. W. (1966). Endotrophic calcium, strontium, and barium spores of Bacillus megaterium and Bacillus cereus. J. Bact. 91, 1333.

GERHARDT, P. \& RiBI, E. (1964). Ultrastructure of the exosporium enveloping spores of Bacillus cereus. J. Bact. 88, 1774.

Gould, G. W. \& Hitchins, A. D. (1963). Sensitization of bacterial spores to lysozyme and hydrogen peroxide with reagents which rupture disulphide bonds. J. gen. Microbiol. 33, 413.

HunNell, J. W. \& ORdal, Z. J. (1961). Cytological and chemical changes in heat killed and germinated bacterial spores. Spores, vol. II. Ed. by H. O. Halvorson. Minneapolis, Minnesota: Burgess Publishing Co.

Kadota, H., Irjma, K. \& Uchida, A. (1965). The presence of keratin-like substance in spore coat of Bacillus subtilis. Agr. Biol. Chem. 29, 870.

KASSEL, B. \& BRAND, E. (1938). The photometric determination of cystine, cysteine, ascorbic acid and related compounds with phosphotungstic acid. J. biol. Chem. 125, 115.

KeYNAN, A., ISSAHARY-Brand, G. \& Evenchik, Z. (1965). Activation of bacterial spores. Spores, vol. III, p. 180. Ed. by L. L. Campbell and H. O. Halvorson. Ann Arbor, Michigan: American Soc. Microbiol.

Keynan, A., Evenchik, Z., Halvorson, H. O. \& Hastings, W. J. (1964). Activation of bacterial endospores. J. Bact. 88, 313.

LEvinson, H. S. \& HyATT, M. T. (1964). Effect of sporulation medium on heat resistance, chemical composition, and germination of Bacillus megaterium spores. J. Bact. 87, 876.

MoORE, S. (1963). On the determination of cystine as cysteic acid. J. biol. Chem. $238,235$.

Moore, S. \& SteIn, W. H. (1948). Photometric ninhydrin method for use in the chromatography of amino acids. J. biol. Chem. 176, 367.

Nossal, P. M. (1953). A mechanical disintegrator. Aust. J. exp. Biol. med. Sci. 31, 583.

OHYE, D. F. \& Murrell, W. G. (1962). Formation and structure of the spores of Bacillus coagulans. J. cell. Biology 14, 111 .

Putnam, F. W. (1953). Protein denaturation. The Proteins, vol. I, p. 808. Ed. by H. Neurath and K. Bailey. New York: Academic Press, Inc.

Reithel, F. J. (1963). The dissociation and association of protein structures. Adv. Protein Chem. $18,12$.

Robinow, C. F. (1960). Morphology of bacterial spores, their development and germination. The Bacteria, vol. I, p. 207. Ed. by I. C. Gunsalus and R. Y. Stanier. New York: Academic Press Inc.

RODE, L. J. \& FOSTER, J. W. (1966a). The effect of exchangeable ions on germinability of bacterial spores. J. Bact. 91, 1582.

Rode, L. J. \& Foster, J. W. (1966 b). Quantitative aspects of exchangeable calcium in bacterial spores. J. Bact. 91, 1589.

RONDLE, C. J. M. \& MoRgAN, W. T. J. (1955). The determination of glucosamine and galactosamine. Biochem. J. 61, 586.

SACKS, L. E. \& Alderton, G. (1961). Behaviour of bacterial spores in aqueous polymer two-phase systems. J. Bact. 82, 331 .

SACKs, L. E. \& Thомаs, R. S. (1965). Internal membranous structure in Bacillus macerans spores. J. Bact. 89, 1615. 

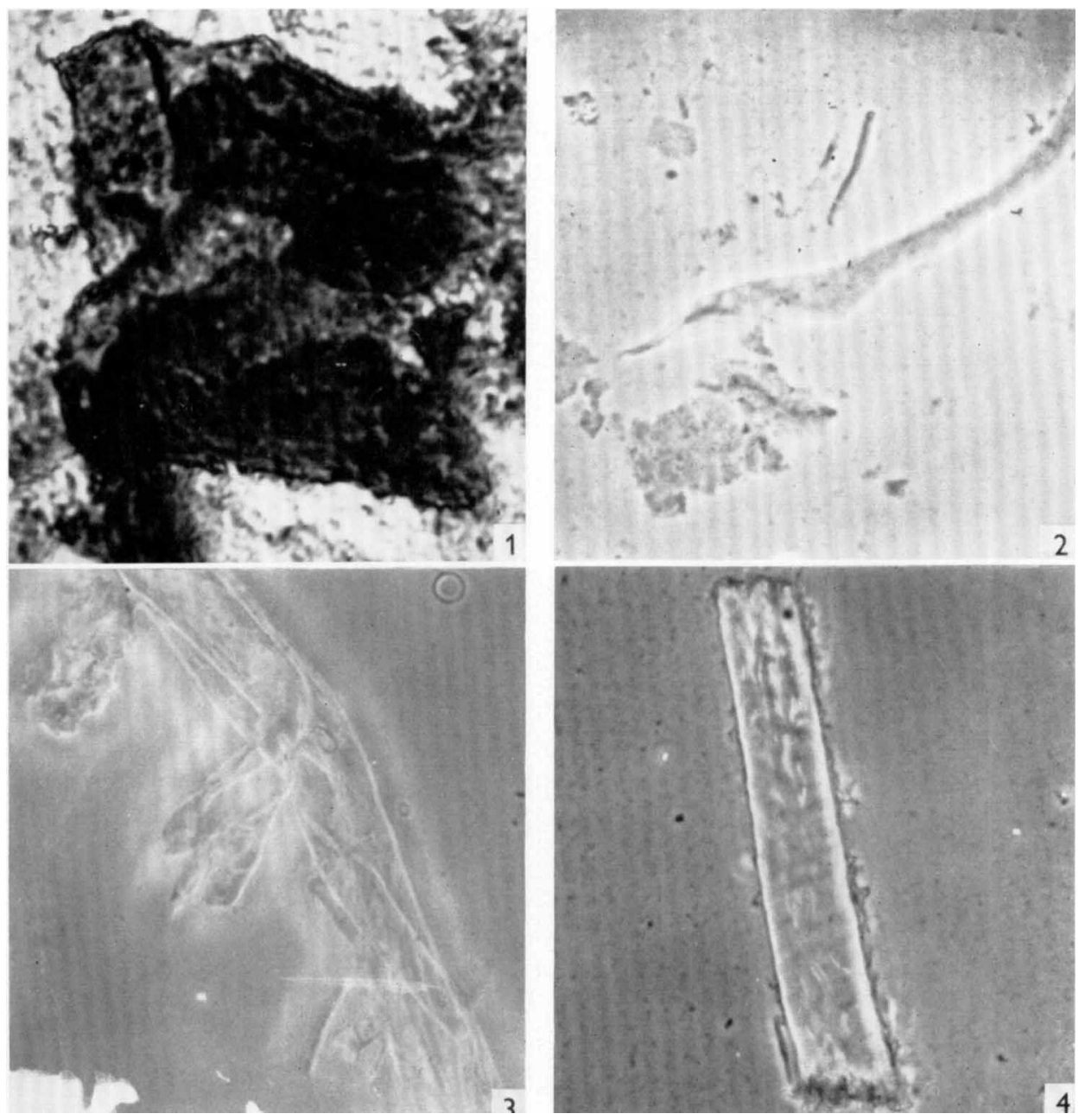


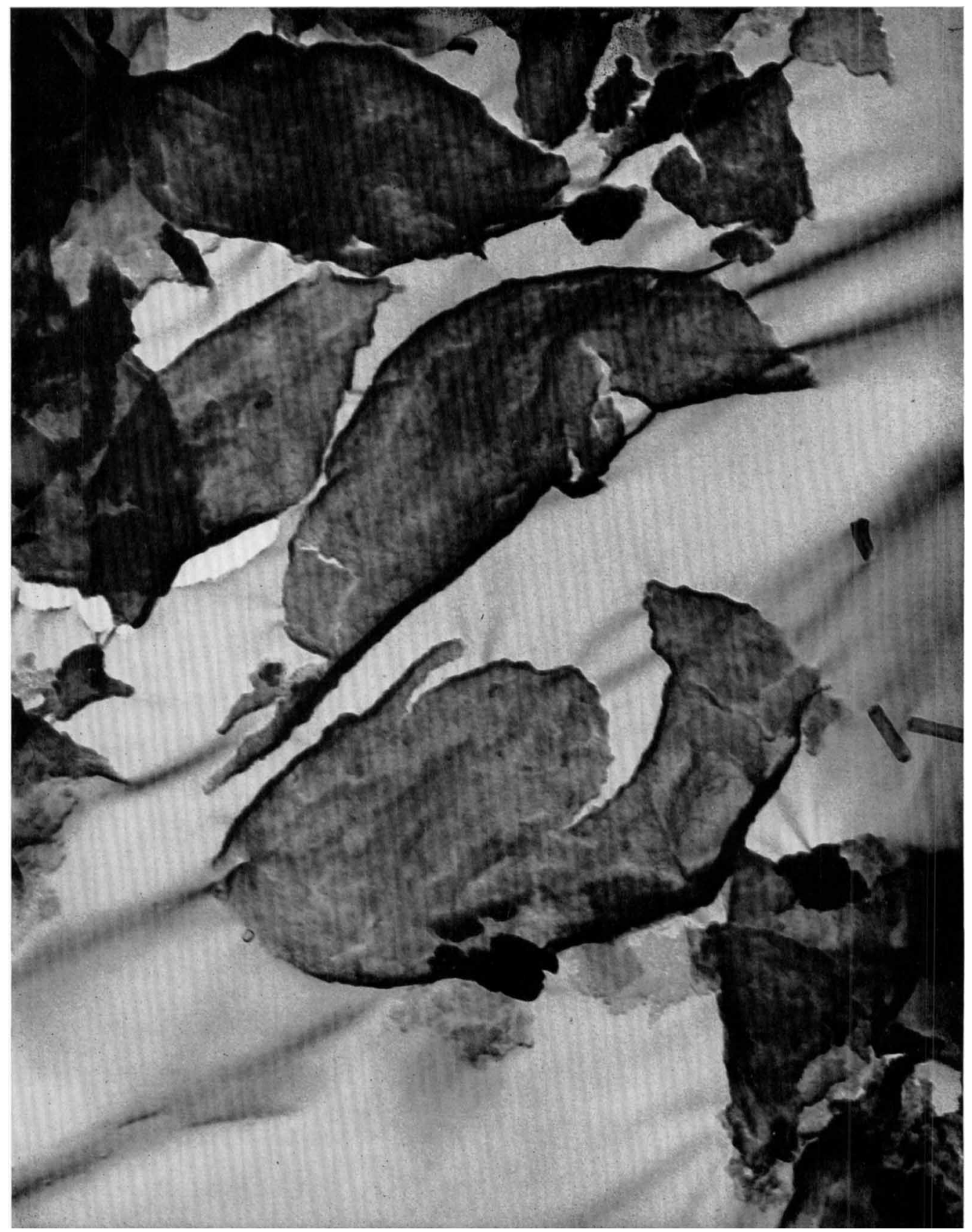

M. KONDO AND THE LATE J. W. FOSTER 

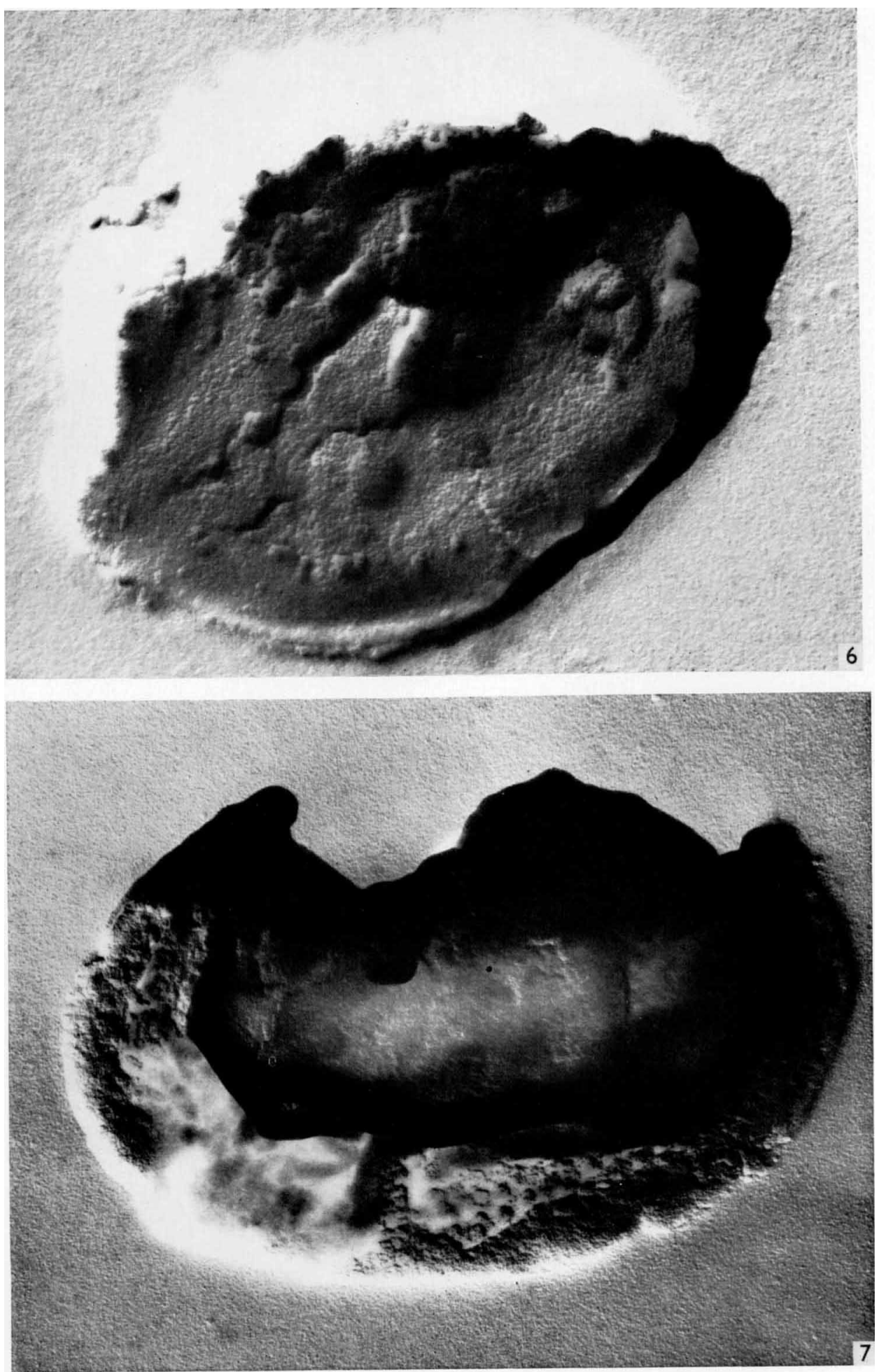
Journal of General Microbiology, Vol. 47, No. 2

Plate 4
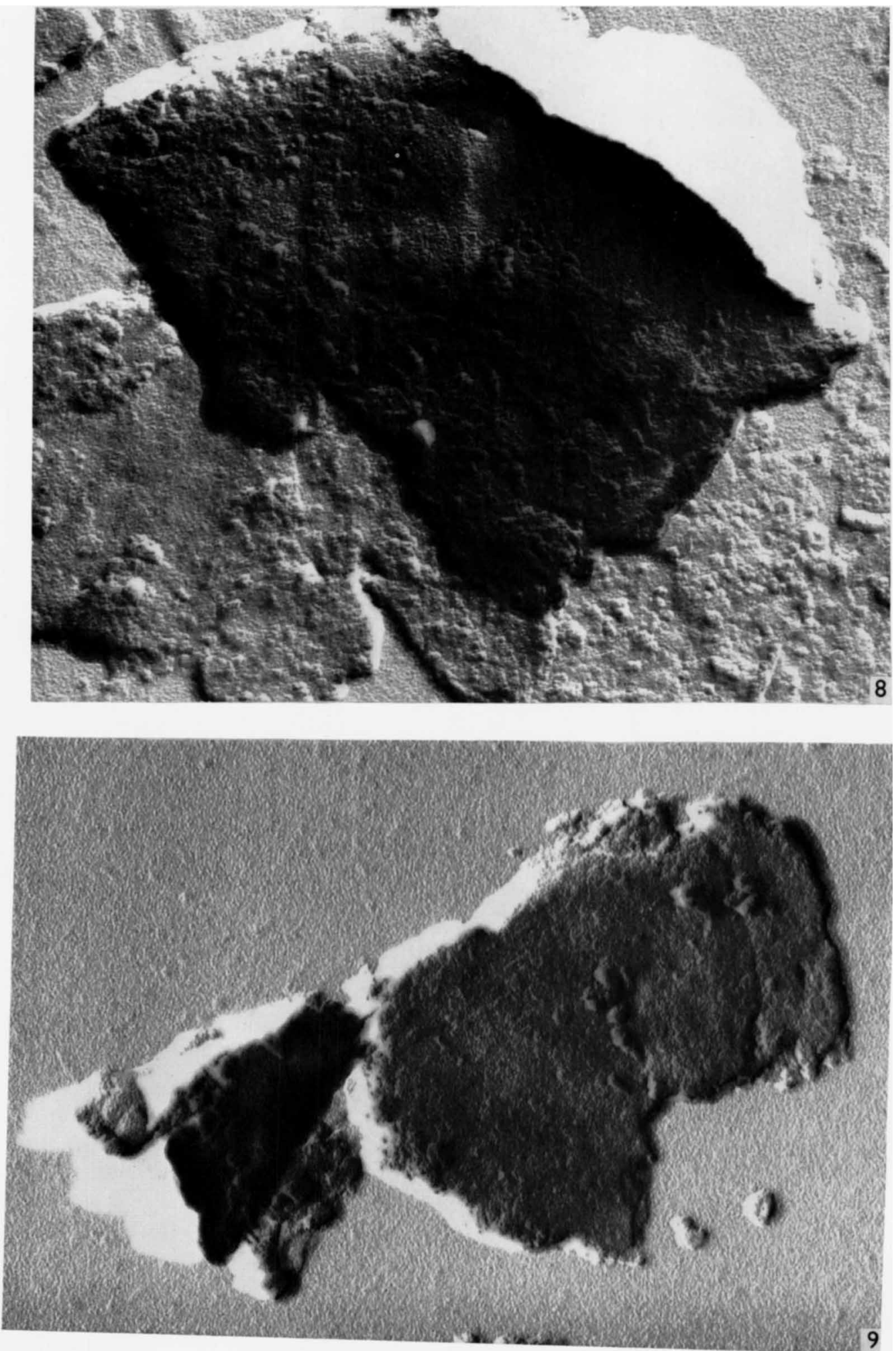
Salton, M. R. J. (1964). The Bacterial Cell Wall. New York: Elsevier.

Salton, M. R. J. \& MARSHALl, B. (1959). The composition of the spore wall and the wall of vegetative cells of B. subtilis. J. gen. Microbiol. 21, 415.

SANGER, F. (1945). The free amino groups of insulin. Biochem. J. 39, 507.

SANGER, F. (1949). The terminal peptides of insulin. Biochem. J. 45, 563.

SNOKE, J. E. (1964). Amino acid composition of Bacillus licheniformis spore coat. Biochem. Biophys. Res. Comm. 14, 571.

StRANGE, R. E. (1960). Glucosamine values of muramic acid and other amino sugars by the Elson and Morgan method. Nature, Lond. 187, 387.

StRANGe, R. E. \& DARK, F. A. (1956). The composition of the spore coats of Bacillus megaterium, B. subtilis, and B. cereus. Biochem. J. 62, 459.

TRISTAM, G. R. \& SMITH, R. H. (1963). The amino acid composition of some purified proteins. Adv. Protein Chem. 18, 227.

VINTER, V. (1961). The formation of cystine-rich structure in sporulating cells and its possible role in the resistance of spores. Spores, vol. II, p. 127. Ed. by H. O. Halvorson. Minneapolis, Minn.: Burgess Publishing Co.

WARTH, A. D. (1965). Composition of mucopeptides from the spores of Bacillus coagulans. Biochim. biophys. Acta 101, 315.

WarTh, A. D., OHYE, D. F. \& MurRelL, W. G. (1963). The composition and structure of bacterial spores. J. Cell Biology 16, 579.

WeIDEL, F. \& PELZER, H. (1965). Bagshaped molecules-a new outlook on bacterial cell walls. Adv. Enzymol. 26, 193.

\section{EXPLANATION OF PLATES}

\section{Plate 1}

Figs. 1-4. Photomicrographs of 'paracrystal' solids that formed spontaneously during in-vacuum concentration of the supernatant fluids from sonic treatment (mild) of $\mathrm{NaOH}$-extracted spore coats (see Fig. 1). Bacillus megaterium $\mathrm{QM}$ B1551; dark-field phase contrast. $\times 1000$.

\section{Plate 2}

Fig. 5. Spore coat fraction of Bacillus megaterium QM B1551. Preparation unshadowed. $\times 35,000$.

\section{Plate 3}

Spore coats of Bacillus megaterium QM B1551 treated with lysozyme. (200 $\mu \mathrm{g}$. enzyme/ml. in $10 \mathrm{~mm}$-tris buffer for $24 \mathrm{hr}$ at 37 ; toluene added). Shadow angle $45^{\circ}$.

Fig. 6 . The treated coat in this photograph appears to be smooth and relatively featureless, although it may be layered. $\times 68,000$.

Fig. 7. The treated coat in this photograph appears to be composed of more or less uniform spherical particles. $\times 100,000$. (A different field from fig. 6.)

\section{Plate 4}

Fig. 8. Spore coats of Bacillus megaterium QM B1551 after successive treatment with lysozyme and extraction with $\mathrm{NaOH}(0.06 \mathrm{~N}-\mathrm{NaOH})$ for $3 \mathrm{hr}$ at $50^{\circ}$. Shadow angle $45^{\circ}, \times 34,000$.

Fig. 9. Spore coat particles of Bacillus megaterium $\mathrm{QM} \mathrm{B} 1551$ resistant to sonic treatment after removal by centrifugation of the paracrystal material. A few paracrystal fraction particles adhere to the smooth basal layer which itself shows some indication of a substructure of uniform particles. Shadow angle $45^{\circ}, \times 100,000$. 